\title{
MEMOTONG KUMIS DAN MEMANJANGKAN JENGGOT BAGI JAMA'AH TABLIGH: STUDI LIVING HADIS DI MASJID AL-ITTIHAD YOGYAKARTA
}

\author{
ULUMMUDIN \\ UIN Sunan Kalijaga Yogyakarta \\ Email: ulummudin53@gmail.com
}

\begin{abstract}
Abstrak
Kumis dan jenggot menjadi salah satu fenomena menarik yang menjadi identitas kelompok Jamaah Tabligh di masjid al-Ittihad Yogyakarta. Hampir seluruh anggotanya tidak ada yang berkumis. Sebaliknya, mereka pasti mempunyai jenggot. Praktek tersebut merupakan bentuk aplikasi terhadap hadis nabi yang memerintahkan untuk senantiasa mencukur kumis dan memelihara jenggot. Hadis tersebut diperoleh dari proses pengajian yang rutin digelar di masjid tersebut. Selanjutnya, fenomena ini dikaji melalui pendekatan teori ideologinya Pierre Bourdieu yang mengenal adanya habitus, doxa, dan arena. Habitusnya adalah menganggap bahwa mencukur kumis dan memelihara jenggot merupakan bagian dari sunnah surah, sedangkan doxanya ialah sosok yang diwakili oleh Pak Yahya yang berperan sebagai takmir masjid. Sementara, arena dari fenomena ini adalah komunitas Jamaah Tabligh di masjid al-Ittihad. Adapun proses ideologisasinya dilakukan secara bertahap melalui kajian tanpa ada paksaan dan disesuaikan dengan kesiapan mental para anggota.
\end{abstract}

\section{Keywords}

Kumis, jenggot, Living Hadis, Bourdieu, Jamaah Tabligh.

\begin{abstract}
Abstact
Mustache and beard are two of the Tablighi Jamaat identities in al-Ittihad mosque which is located in Yogyakarta. Most of their members do not have mustache but keep beard. These practices are a form of aplication toward hadiths which order to cut mustache and own beard. The hadiths are gained from the process of learning which is continuously conducted in the mosque. This phenomenon is analyzed by using theory of ideology of Pierre Bourdieu which consists of habitus, doxa, and arena. The habitus is deeming that cutting mustache and keeping beard are part of the sunnah of appearance, while the doxa is Mr. Yahya as a leader of the mosque. The arena of this phenomenon is Tablighi Jamaat community in al-Ittihad mosque. Besides, the process of ideology is applied gradually by a lesson without forcing and it is based on mental readiness of the members.
\end{abstract}

\section{Keywords}

Mustache, Beard, Living Hadith, Bourdieu, Tablighi Jamaat. 


\section{Pendahuluan}

Pendahulan harus menggambarkan dengan jelas latar belakang penelitian, tujuan dan manfaat penelitian, literatur-literatur yang relevan dengan dengan subjek penelitian, pendekatan yang akan digunakan, serta nilai kebaharuan yang akan dihasilkan. Istilah-istilah asing dicetak miring (italic).Menggunakanspasi exactly 17

Kemunculan Jamaah Tabligh di India pada awal abad ke-20 menjadi fenomena tersendiri. Dua puluh tahun sejak kelahirannya, gerakan dakwah ini telah melebarkan sayapnya ke berbagai negara salah satunya Indonesia. ${ }^{1}$ Yogyakarta sebagai salah satu kota besar dan sekaligus kota pelajar tak luput dari sasarannya. Dalam perkembangannya di kota ini, Jamaah Tabligh berhasil menarik banyak simpati, sehingga mereka mendirikan markas yang berlokasi di masjid al-Ittihad jalan Kaliurang KM 5, Depok, Sleman.

Dalam praktek kesehariannya, kelompok ini dikenal sebagai kelompok yang berusaha untuk menghidupkan masa lalu yang memiliki akar dari praktek-praktek yang dilakukan oleh nabi. ${ }^{2}$ Praktek-praktek tersebut terekam dalam bentuk hadis yang dapat ditemukan dalam kitabkitab yang menghimpun hadis-hadis nabi. Itu mengindikasikan bahwa teks hadis mempunyai power yang signifikan dalam menentukan corak kehidupan kelompok ini. Mereka menjadikan teks baik al-Qur'an maupun hadis sebagai kritik terhadap budaya yang tidak sesuai dengan Islam. Implikasinya, teks membentuk suatu tradisi baru yang sekaligus merespons tradisi lain. ${ }^{3}$

Praktek-praktek tersebut salah satunya tercermin dalam penampilan fisik kelompok Jamaah Tabligh. Mereka biasanya memelihara jenggot, tidak memelihara kumis, berisbal, memakai gamis ala India atau Pakistan, menggunakan siwak, dan memakai kopiah atau sorban. Bagi mereka, segala atribut yang menempel kepada nabi adalah sunnah yang bersumber dari wahyu Allah, sehingga harus diikuti. Mereka tidak memandangnya sebagai budaya Arab dimana nabi hidup. ${ }^{4}$

Penelitian ini mengambil salah satu sample dari praktek-praktek tersebut yakni perihal kumis dan jenggot. Jarang sekali seseorang yang menjadi bagian dari Jamaah Tabligh mempunyai kumis. Sebaliknya, mereka lebih memilih untuk memelihara jenggot. Mereka akan senantiasa mencukur kumis dan memanjangkan jenggot sebagai salah satu identitas penampilannya.

Kemudian, latar belakang munculnya fenomena tersebut perlu untuk diungkap. Apa teks hadis yang meligitimasi praktek mencukur kumis dan memelihara jenggot di kalangan Jamaah Tabligh di masjid al-Ittihad? Serta, bagaimana proses ideologisasinya, sehingga praktek mencukur kumis dan membiarkan jenggot dianggap sebagai bagian dari identitas kelompok ini?

\footnotetext{
${ }^{1}$ Muhammad Zaki, "Metode Pemahaman dan Pengamalan Hadits Jamaah Tabligh", Jurnal Pengembangan Masyarakat Islam, Vol. 8, No. 2, 2015, h. 107.

${ }^{2}$ Harun Nasution, Pembaharuan dalam Islam, Sejarah Pemikiran dan Gerakan. (Jakarta: Bulan Bintang, 1996), h. 163.

${ }^{3}$ Saifuddin Zuhri dan Subhani Kusuma Dewi, Living Hadis: Praktik, Resepsi, Teks, dan Transmisi. (Yogyakarta: Q-Media, 2018), h. 39.

${ }^{4}$ Muhammad Zaki, "Metode Pemahaman dan Pengamalan Hadits Jamaah Tabligh”, Jurnal Pengembangan Masyarakat Islam, h. 105.
} 
Permasalahan tersebut akan berusaha dijelaskan menggunakan perspektif living hadis yang berawal dari sebuah fenomena pada komunitas Jamaah Tabligh di masjid al-Ittihad. Teori yang digunakan untuk menjelaskan tahapan ideologisasi adalah teori ideologi Pierre Bourdieu. Teori ini meniscayakan adanya habitus, doxa, dan arena.

Habitus merupakan hasil keterampilan yang menjadi tindakan praktis yang kemudian diterjemahkan menjadi suatu kemampuan yang terlihat alamiah. Habitus memberi arahan terhadap apa yang sebaiknya dipilih untuk dilakukan. Contohnya, seperti kebiasaan makan dengan tangan kanan yang sudah terpatri sejak kecil. ${ }^{5}$ Sementara, doxa adalah sejenis tatanan sosial dalam diri individu yang stabil dan terikat pada sebuah tradisi tanpa dipertanyakan. Adapun arena adalah konsep tentang dunia sosial sebagai bentuk bagian kecil dari dunia sosial yang bekerja secara mandiri dengan hukumnya sendiri, misalnya arena politik, seni, agama, dsb. ${ }^{6}$

\section{Sejarah dan Perkembangan Jamaah Tabligh}

Jamaah Tabligh merupakan gerakan dakwah bercorak sufi yang berasal dari India. Pendirinya adalah Maulana Muhammad Ilyas bin Muhammad Ismail al-Kandahlawi al-Deobandi al-Jisyti. Kandahlawi dinisbatkan pada sebuah kampung yang terletak di Saharanfur India. Sementara, Deoband adalah nama sebuah desa dimana terdapat sebuah madrasah yang dikenal dengan Darul Ulum. Madrasah yang berdiri pada tahun $1288 \mathrm{H}$ ini mengajarkan teologi Asy'ariyah dan fiqih yang bermazhab Hanafi. Di samping itu, hadis juga menjadi kajian utama di madrasah ini. Adapun al-Jisyti adalah sebuah nama tarekat sufi al-Jisytiyah yang dianut oleh Maulana Ilyas. ${ }^{7}$

Syaikh Maulana Ilyas al-Kandahlawi dilahirkan pada tahun $1303 \mathrm{H}$ atau bertepatan dengan 1886 Masehi. Riwayat pendidikannya, beliau pernah belajar di Darul Ulum Doeband kepada Mahmud Hasan. Di sana beliau mempelajari ilmu agama utamanya hadis. Setelah beliau wafat kepemimpinan diteruskan oleh puteranya yang bernama Muhammad Yusuf al-Kandahlawi (1917-1965). Pada kedua kepemimpinan ini, kegiatan jamaah tablig masih terbatas hanya di wilayah India. $^{8}$

Kemunculan gerakan ini dilatar belakangi oleh setidaknya tiga hal. Pertama, keprihatinan Muhammad Ilyas atas kemunduran keagamaan dan rendahnya akhlak umat Islam. Ajaran Islam telah tercampur dengan ajaran lain yang tidak sesuai. Hal ini berimplikasi pada perilaku seharihari yang sangat jauh dari nilai-nilai agama. ${ }^{9}$ Fakta demikian mendorong Syaikh Ilyas untuk melakukan dakwahnya di tengah masyarakat.

\footnotetext{
${ }^{5}$ George Ritzer dan Douglas Goodman, Teori Sosiologi Modern. (Jakarta: Kencana, 2003), h. 523-524.

${ }^{6}$ Eka Ningtyas, "Pierre Bourdieu, Langue and Syimbolic Power", Jurnal Poetika, Vol. 3, No. 2, 2015 , h. 155.

${ }^{7}$ Muhammad Zaki, “Metode Pemahaman dan Pengamalan Hadits Jamaah Tabligh”, Jurnal Pengembangan Masyarakat Islam, h. 106.

8 Sayyid Abu Hasan Ali Syari'ati Nadwi, Maulana Muhammad Ilyas, terj. Masrokhan Ahmad. (Yogyakarta: Ahs-Shaff, 1999), h. 5.

${ }^{9}$ Gulam Musthafa Ahmad, Menyingkap Tabir Kesalahpahaman Terhadap Jama'ah Tabligh, terj. Ahmad Najib Mahfuzh. (Yogyakarta: Ash-Shaf, 1997), h. 14.
} 
Kedua, saat Maulana Ilyas hidup, India sedang berada di bawah koloni Inggris. Orangorang Ingris yang menganut Kristen berusaha untuk melakukan Kristenisasi di negeri jajahannya. Oleh karena itu, sebagai seorang terpelajar beliau merasa khawatir dan gelisah serta merasa mempunyai tanggung jawab untuk menghalau misionaris. ${ }^{10}$

Ketiga, melihat realitas masyarakat yang demikian, Jamaah Tabligh lahir juga karena terinspirasi oleh ayat al-Qur'an yakni Q.S Ali Imran: $110^{11}$ yang berbunyi:

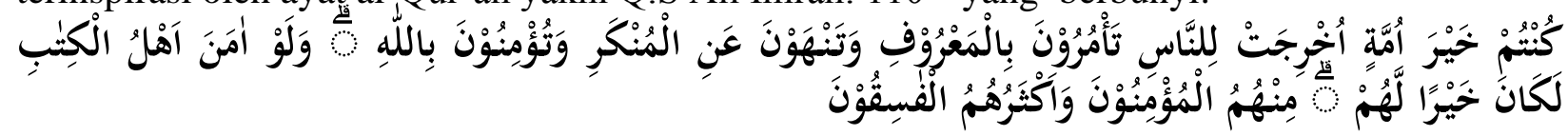

Artinya:

"Kamu adalah umat yang terbaik yang dilahirkan untuk manusia, menyuruh

kepada yang ma'ruf, dan mencegah dari yang munkar, dan beriman kepada

Allah. Sekiranya ahli kitab beriman, tentulah itu lebih baik bagi mereka, di

antara mereka ada yang beriman, dan kebanyakan mereka adalah orangorang yang fasik."

Ayat di atas menjadi dasar Jamaah Tabligh untuk melakukan dakwahnya. Kata ukhrijat pada ayat tersebut dipahami sebagai sebuah metode untuk mengajak manusia dalam kebaikan dan menjauhi keburukan. Oleh karena itu, tidak mengherankan jika gerakan ini identik dengan istilah khuruj yang berarti keluar secara literal.

Setelah kegelisahan tersebut muncul dan beliau menemukan inspirasi dari ayat al-Qur'an, tiba saatnya untuk memikirkan langkah nyata yang harus ditempuh dalam usaha dakwahnya. Untuk memantapkan hatinya, beliau pergi menunaikan haji untuk beribadah dan berdoa di sana. Selepas pulang, ia merasa mendapat petunjuk dari Allah bahwasanya gerakan dakwah akan berhasil jika dilakukan berdasarkan pada keikhlasan (mengharap ridho dan pertolongan Allah) dan pengorbanan. Dua kata ini menjadi kunci yang harus dipegang oleh para jamaah. Untuk mengamalkan keduanya, maka dalam Jamaah Tabligh dikenal adanya konsep khuruj yakni meluangkan waktu untuk mengajak manusia ke jalan yang benar dengan melakukan dakwah di jalan Allah. ${ }^{12}$

Berawal dari India gerakan ini berkembang dengan pesat. Para pendakwah memperluas jangkauan dakwahnya sampai ke Timur Tengah, Asia Tenggara, Afrika, Eropa, dan Amerika. Tak butuh waktu lama bagi gerakan ini untuk menancapkan pengaruhnya di segala penjuru dunia, tak terkecuali Indonesia. ${ }^{13}$

10 Muhammad Zaki, "Metode Pemahaman dan Pengamalan Hadits Jamaah Tabligh", Jurnal Pengembangan Masyarakat Islam, h. 107.

${ }^{11}$ Muhammad Mukhlis, "Telaah Hadis-Hadis yang Digunakan sebagai Hujjah Jama'ah Tabligh Masjid Jami’ Kebon Jeruk Jakarta Barat” Skripsi Fakultas Ushuluddin UIN Syarif Hidayatullah, 2011, h. 9.

12 Muhammad Zaki, "Metode Pemahaman dan Pengamalan Hadits Jamaah Tabligh", Jurnal Pengembangan Masyarakat Islam, h. 107.

13 Jhon L. Esposito, “Jama'ah Tablig”, dalam Ensiklopedi Oxford Dunia Islam Modern, Jilid 4, terj. Eva,Y.N., dkk, ed. Ahmad Baiquni. (Bandung: Mizan, 2001), h. 38. 


\section{Prinsip dan Metode Dakwah Jamaah Tabligh}

Setidaknya ada enam prinsip yang harus dipegang teguh oleh para pengikut Jamaah Tabligh. ${ }^{14}$ Pertama, berpegang teguh pada kalimat toyyibah yakni La Ilaha illa Allah Muhammad al-Rasulullah. Kalimat ini merupakan pengakuan keyakinan terhadap ketauhidan, menyembah kepada Allah sesuai dengan cara yang diajarkan Rasulullah. Kedua, salat khusu dan khudu', mendirikan salat dengan rukun dan sunnah yang sempurna serta khusu' dalam mengerjakannya. Salat yang demikian akan berpengaruh untuk mencegah hal-hal yang keji dan munkar. Jika orang Islam masih melakukan perbuatan keji dan munkar berarti salatnya belum khusu' dan khudu'. Ketiga, ilmu dan dzikir. Mempelajari merupakan suatu kewajiban, sedangkan mengamalkannya adalah salah satu bentuk dzikir karena ilmu tanpa amal akan menjadi tidak bermanfaat. Keempat, memuliakan setiap muslim. Maksudnya mewujudkan kembali persaudaraan yang mungkin selama ini agak renggang. Sudah seyogianya, sesama muslim harus saling memuliakan agar tercipta suatu hubungan yang harmonis. Kelima, meluruskan niat. Setiap muslim dalam setiap amalnya harus semata-mata mengharap keridhan Allah. Tanpa ada sebuah niat yang tulus, setiap perbuatan akan terasa berat dan tidak bernilai di hadapan Allah. Keenam, dakwah dan khuruj di jalan Allah. Setiap muslim mempunyai kewajiban untuk mengajak kebaikan dan mencegah keburukan. Tujuannya supaya manusia tidak tersesat dan merah kebahagiaan di dunia dan akhirat.

Adapun metode dakwah Jamaah Tabligh adalah sebagai berikut: ${ }^{15}$ Pertama, sebuah kelompok dari kalangan Jama'ah, dengan kesadaran sendiri, bertugas melakukan dakwah kepada penduduk setempat yang dijadikan obyek dakwah. Masing-masing anggota kelompok tersebut membawa peralatan hidup sederhana dan bekal serta uang secukupnya. Kedua, jika saat bayan tiba, mereka semua berkumpul untuk mendengarkannya. Setelah bayan selesai, para hadirin dibagi menjadi beberapa kelompok. Setiap kelompok dipimpin oleh seorang da'i dari Jama'ah. Kemudian para da'i tersebut mulai mengajari cara berwudhu', membaca fatihah, shalat atau membaca Alquran. Mereka membuat halaqah-halaqah seperti itu dan diulanginya berkali-kali dalam beberapa hari. Ketiga, sebelum mereka meninggalkan tempat dakwah, masyarakat setempat diajak keluar bersama untuk menyampaikan dakwah ke tempat lain. Beberapa orang secara sukarela menemani mereka selama satu sampai 3 hari atau sepekan, bahkan ada yang sampai satu bulan dan bahkan 40 hari. Semua itu dilakukan sesuai dengan kemampuan masingmasing sebagai pengamalan terhadap Q.S. Ali Imran: 110 yang telah disebutkan di atas. Keempat, menolak undangan walimah yang diselenggarakan penduduk setempat. Kelima, dalam materi dakwah, mereka tidak memasukkan ide penghapusan kemunkaran. Sebab mereka meyakini bahwa sekarang ini masih berada dalam tahap pembentukan kondisi kehidupan yang Islami. Keenam, Mereka berkeyakinan, jika pribadi-pribadi telah diperbaiki satu persatu, maka secara otomatis kemunkaran akan hilang. Ketujuh, keluar, tabligh dan dakwah merupakan

${ }^{14}$ Furqan, "Peran Jamaah Tabligh dalam Pengembangan Dakwah”, jurnal Al-Bayan, Vol. 21, No. 2, 2015, h. 4-5.

${ }^{15}$ Budimansyah, "Gerakan Islam Jama'ah Tabligh dalam Tinjauan Maqashid al-Din”, Jurnal Al- 'Adalah, Vol. 10, No. 3, 2012, h. 265. 
pendidikan praktis untuk menempa seorang da'i. Sebab seorang da'i harus dapat menjadi panutan dan harus konsisten dengan dakwahnya.

\section{Pandangan Jamaah Tabligh Terhadap Sunnah dan Hadis}

Dalam memahami sunnah, Jamaah Tabligh cenderung pada definisi yang disampaikan oleh ulama hadis, yakni segala sesuatu yang datang dari Nabi baik berupa perkataan, perbuatan, taqrir, sifat fisik maupun non fisik, sebelum menjadi rasul maupun sesudahnya. Mereka beranggapan bahwa segala sesuatu yang disandarkan kepada Nabi adalah berasal dari wahyu. Semua yang dilakukan Nabi dari mulai bangun tidur sampai menjelang tidur merupakan bagian dari sunnah. Oleh sebab itu, umat Islam perlu untuk mencontoh dan menirunya. ${ }^{16}$

Dalam hal ini, Jamaah Tabligh membagi kategori sunnah menjadi tiga bagian. ${ }^{17}$ Pertama, surah yaitu penampilan yang melekat pada Nabi secara fisik dalam kehidupan sehari-harinya. Yang termasuk kategori ini adalah pakaian berjubah, gamis, berisbal, sorban, memanjangkan jenggot, tidak memelihara kumis, menggunakan celak, dan sebagainya. Para anggota Jamaah Tabligh akan berusaha untuk meniru hal tersebut sebagai upaya untuk menghidupkan sunnah. Kedua, sirah yakni tindakan nabi atau perjalanan hidup beliau. Yang termasuk ke dalam kategori ini adalah cara makan dan minum, cara salat, cara tidur, dan sebagainya. Sirah menjadi model bagi jamaah sebagai panduan dalam bertindak dan bersikap. Ketiga, sarirah yaitu mencakup halhal batiniah seperti pikiran dan perasaan nabi. Contohnya seperti kepedulian nabi terhadap umatnya. Beliau memikirkan keselamatan mereka bukan hanya di dunia tapi juga di akhirat.

Jadi, dari gambaran di atas dapat dipahami bahwa Jamaah Tabligh berusaha untuk bertindak, bertutur, dan berpenampilan sesuai dengan yang telah nabi lakukan. Mereka menganggap semua atribut yang dinisbatkan kepada nabi adalah sunnah, sehingga itu akan bernilai ibadah jika dilakukan. Maka, tak salah jika kelompok ini disebut sebagai kelompok revivalis atau kelompok yang ingin menghidupkan masa lalu sesuai dengan tuntunan nabi. ${ }^{18}$

Berbicara tentang revivalis, Menurut Harun Nasution, ada tiga ciri kelompok revivalis dalam Islam; pertama, menafsirkan agama dengan bersifat literal. Kedua, mencoba menghidupkan kembali figur-figur sejarah dalam konteks sekarang. Ketiga, pemikiran yang bermuara pada obsesi tentang masyarakat yang ideal seperti idealitas masyarakat pada masa Nabi Saw. ${ }^{19}$ Ciri-ciri tersebut nampaknya, relevan dengan kelompok Jamah Tabligh dalam memandang era kontemporer dengan berdasarkan sunnah.

\section{Jamaah Tabligh di Yogyakarta}

Perkembangan Jamaah Tabligh sangatlah pesat. Dalam rentang 20 tahun sejak didirikannya, ia sudah tersebar ke berbagai penjuru dunia seperti Timur Tengah, Eropa, Afrika, Amerika, tak terkecuali Indonesia. Di Indonesia sendiri Jamaah Tabligh memulai aktivitasnya

16 Muhammad Zaki, "Metode Pemahaman dan Pengamalan Hadits Jamaah Tabligh", Jurnal Pengembangan Masyarakat Islam, h. 108.

17 Yahya, Ta'mir masjid Al Ittihad, 3 Oktober 2018.

18 M. Nurdin Zuhdi, "Kritik Terhadap Pemikiran Gerakan Keagamaan Kaum Revivalisme Islam di Indonesia," Akademika: Jurnal Pemikiran Islam, Vol. 16 No. 2, 2011, h. 92.

${ }^{19}$ Harun Nasution, Pembaharuan dalam Islam, Sejarah Pemikiran dan Gerakan, h. 163. 
tahun 1954 dan membuahkan hasil pada sekitar tahun 70an sampai sekarang. Keberhasilan ini tak lepas dari metode dakwah mereka yang dapat merangkul orang awam. Dakwah mereka sederhana yakni mengajak untuk memakmurkan masjid dan menghidupkan sunnah-sunnah Nabi. ${ }^{20}$ Selain itu, faktor lain yang memudahkan kelompok ini diterima adalah mereka tidak berafiliasi kepada politik apapun, sehinggga gerakannya murni gerakan keagamaan yang mengajak amar makruf nahi munkar. Hal ini berdasarkan pengalaman penulis ketika bergaul dengan Jamaah Tabligh.

Dalam setiap wilayah Jamaah Tabligh mempunyai pusat atau dalam istilah mereka disebut markaz. Adapun markaz pusat Jamaah Tabligh dunia terletak di tiga negara yakni Nizamuddin di kota New Delhi India, Rewind di kota Lahore Pakistan, dan Tungi di Bangladesh. ${ }^{21}$ Sementara untuk Indonesia pusatnya berada di Masjid Kebon Jeruk Jakarta. Untuk para anggota yang akan berangkat ke IPB (India, Pakistan, dan Bangladesh) biasanya ditampung di tempat tersebut. Adapun untuk wilayah Yogyakarta berpusat di Masjid al-Ittihad yang berlokasi di jalan Kaliurang KM 5 Depok, Sleman.

Sebelum memperoleh keberhasilan dakwahnya di Indonesia, Jamaah Tabligh pernah mendapatkan penolakan. Keberhasilan dakwah Jamaah Tabligh di Indonesia tak lepas dari salah satu peran yang dimainkan oleh Maulana Lutfhurrahman dan muridnya Saleh bin Usman Jalaluddin. Mereka datang ke Jakarta untuk berdakwah selama 40 hari pada tahun 1974. Ketika berdakwah mereka ditemani oleh $\mathrm{H}$. Ahmad Zulfikar yang kemudian bergabung dengan Jamaah Tabligh dan mendirikan markaz Jamaah Tabligh Indonesia yang berpusat di Jakarta. Dari sini Jamaah Tablig markaz Indonesia memulai hubungannya dengan Nizamuddin di India. ${ }^{22}$ Setelah itu, program dakwah ke berbagai penjuru negeri dimulai. Yogyakarta menjadi salah satu kota yang tak luput dari sasaran dakwah.

Sebelum membentuk markaz di masjid al-Ittihad, kelompok Jamaah Tabligh ketika pertama kali berdakwah di Yogyakarta, mendatangi masjid Ukhuwah Islamiyyah berlokasi di dekat stasiun, Lempuyangan. Ini terjadi pada tahun 1988 Masehi. Saat itu, jamaah-jamaah yang datang mayoritas berasal dari luar negeri seperti India, Pakistan, dan Malaysia. Namun, kedatangan mereka mendapatkan penolakan dari warga sekitar karena dianggap meresahkan. ${ }^{23}$ Masyarakat merasa asing dengan kegiatan yang dilakukan oleh mereka, sehingga menimbulkan kecurigaan.

Untuk menghindari gesekan, kelompok Jamaah Tabligh ini pergi untuk mencari masjid lain yang bersedia menampung mereka. Dalam keadaan yang demikian, masjid al-Ittihad

20 Muhammad Zaki, "Metode Pemahaman dan Pengamalan Hadits Jamaah Tabligh", Jurnal Pengembangan Masyarakat Islam, h. 107-108.

${ }^{21}$ Furqan, "Peran Jamaah Tabligh dalam Pengembangan Dakwah", Jurnal Al-Bayan, Vol. 21, No. 2, 2015, h. 6 .

${ }^{22}$ Ibnu Satyahadi, “Kegiatan Khuruj dan Dinamika Keluarga Jama'ah Tabligh (Studi pada Anggota Jama'ah Tabligh dan Keluarga di Masjid Jami' Al-Ittihad Jalan Kaliurang Km. 5 Kecamatan Depok Kabupaten Sleman Provinsi Daerah Istimewa Yogyakarta)", Skripsi Fakultas Ilmu Sosial dan Humaniora UIN Sunan Kalijaga, 2014, h. 48-49.

${ }^{23}$ Ismi Syayuman, "Khuruj dalam Jama'ah Tabligh: Studi Terhadap Pengikut Jama'ah Tabligh di Masjid Jami' Al Ittihad Jalan Kaliurang KM. 5, Kecamatan Depok, Kabupaten Sleman, Provinsi Daerah Istimewa Yogyakarta" Skripsi Fakultas Ushuluddin UIN Sunan Kalijaga, 2007, h. 45. 
memainkan perannya. Takmir masjid al-Ittihad yang saat itu dipegang oleh K.H. Na'man Zaini menyambut mereka dengan ramah. Selama beberapa hari, mereka tinggal di sana dan menjalankan aktivitas dakwahnya. Sama dengan kejadian di masjid yang pertama, masyarakat mempertanyakan kegiatan tersebut. Namun, Na'man Zaini selaku takmir dapat mengendalikannya. Ia tidak serta merta menolaknya, melainkan mempelajari Jamaah Tabligh terlebih dahulu. ${ }^{24}$

Bahkan, karena ketertarikannya ini, Na'man Zaini memutuskan untuk pergi ke Nizamuddin, markaz pusat di India. Di sana ia melakukan khuruj selama kurang lebih lima bulan. Setelah ia kembali, sejak saat itu masjid al-Ittihad yang terletak di jalan Kaliurang KM 5 resmi menjadi markaz Jamaah Tabligh untuk area Yogyakarta. ${ }^{25}$ Sampai saat ini masjid ini masih eksis sebagai pusat Jamaah Tabligh Jogja. Para da'i dari berbagai daerah di dalam negeri maupun luar negeri akan singgah di sini ketika mereka datang ke Yogyakarta. Dari masjid ini para da'i diorganisir dan disebar ke berbagai masjid yang terdapat di wilayah Yogyakarta.

Dengan demikian, sekilas nampak bahwa Jamaah Tabligh merupakan suatu organisasi yang mempunyai struktur yang jelas dengan Anggaran Dasar dan Anggaran Rumah Tangganya (AD/ART). Namun, hal ini dibantah oleh Pak Yahya. Ia mengatakan Jamaah Tabligh murni sebagai usaha dan gerakan dakwah. ${ }^{26}$ Walaupun demikian, mereka mempunyai struktur kepengurusan dari amir tertinggi sampai penanggung jawab di masing-masing kecamatan dan desa. Susunan penanggung jawab ini didasarkan pada hirarki atau jangkauan kerja jamaah, yang terdiri dari: ${ }^{27}$

1. Hadraj yaitu orang yang dihormati;

2. Majelis Syuro dan Zumidar yaitu majelis musyawarah dan penanggung jawab di setiap negara, provinsi, kotamadya, dan kabupaten;

3. Karkun yakni ahli dakwah pada setiap masjid atau mushola yang ditugaskan untuk memakmurkan tempat tersebut.

Jika melihat hirarki di atas, maka masjid al-Ittihad berfungsi sebagai tempat atau pusat majelis syuro dan zumidar karena di tempat ini kerja dakwah untuk wilayah Daerah Istimewa Yogyakarta dirumuskan.

Kegiatan rutin yang diselenggarakan di masjid ini juga menguatkan fungsinya sebagai tempat majelis syuro. Menurut penuturan Pak Yahya setiap hari Senin diadakan musyawarah yang melibatkan semua halaqah dari wilayah DIY. Selain itu, setiap malam Jum'at diselenggarakan pula ijtima yang melibatkan seluruh anggota Jamaah Tabligh baik yang akan melaksanakn khuruj maupun tidak. Kegiatan ini dimulai setelah salat ashar sampai pagi setelah subuh di hari berikutnya. Acaranya dipenuhi dengan bayan atau ta'lim dan bentuk ibadah

${ }^{24}$ Ibnu Satyahadi, "Kegiatan Khuruj dan Dinamika Keluarga Jama'ah Tabligh (Studi pada Anggota Jama'ah Tabligh dan Keluarga di Masjid Jami' Al-Ittihad Jalan Kaliurang Km. 5 Kecamatan Depok Kabupaten Sleman Provinsi Daerah Istimewa Yogyakarta)", h. 50.

${ }^{25}$ Ibnu Satyahadi, Skripsi "Kegiatan Khuruj dan Dinamika Keluarga Jama'ah Tabligh (Studi pada Anggota Jama'ah Tabligh dan Keluarga di Masjid Jami' Al-Ittihad Jalan Kaliurang Km. 5 Kecamatan Depok Kabupaten Sleman Provinsi Daerah Istimewa Yogyakarta)", h. 51.

${ }^{26}$ Yahya, Ta'mir masjid Al Ittihad, 3 Oktober 2018.

${ }^{27}$ Furqan, "Peran Jamaah Tabligh dalam Pengembangan Dakwah", h. 6. 
lainnya seperti membaca al-Qur'an dan tahajud. Kitab Fadhail al-Amal dan Hikayat Shabat menjadi kitab yang diulas pada kegiatan bayan ini. ${ }^{28}$

Selain dua kitab di atas, Jamaah Tabligh juga biasanya membaca kitab Riyadh alSalihin $^{29}$, Tablighi Nisab, dan Fadhail al-Qur'an. Kitab-kitab tersebut mempunyai kedudukan yang sangat penting di kalangan Jamaah Tabligh. Bahkan, kitab tersebut banyak diterjemahkan ke dalam berbagai bahasa seperti Urdu, Inggris, Jerman, dan lain sebagainya. Menurut Barbara Metcalf seperti yang dikutip oleh Saifuddin Zuhri dan Subhani Kusuma Dewi kitab-kitab tersebut berperan dalam membentuk jati diri dan karakter Jamaah Tabligh. Karakter tersebut digambarkan dalam dua poin. Pertama, Jamaah Tabligh menolak modernisme dan mengajak untuk takut karena Allah. Kedua, Jamaah Tabligh ingin menunjukkan diri sebagai komunitas yang selalu mencintai al-Qur'an. ${ }^{30}$

\section{Pandangan Jamaah Tabligh di Masjid al-Ittihad Terhadap Kumis dan Jenggot}

Sebagaimana penjelasan di atas bahwa Jama'ah Tabligh erat kaitannya dengan kitabkitab tertentu yang salah satunya adalah Fadhail al-Amal. Kitab yang dikarang oleh Maulana Zakariyya ini menjadi pedoman utama di kalangan Jama'ah Tabligh, maka tak heran dalam taklim-taklim yang diadakan oleh mereka, kitab ini disampaikan. Buku ini sendiri berisikan keutamaan-keutamaan dalam berbagai amalan ibadah seperti membaca al-Qur'an, salat, dzikir, ramadhan, dan tabligh. Keutamaan-keutamaan tersebut didasarkan pada informasi yang terdapat dalam hadis-hadis nabi. Oleh sebab itu, kitab ini diproyeksikan sebagai motivator bagi pengikut Jamaah Tabligh karena berlandaskan tuntunan nabi.

Selain itu, mereka juga rutin mengkaji kitab Riyadh al-Shalihin karangan Imam Nawawi. Kitab ini menghimpun hadis-hadis pilihan mengenai tema-tema tertentu yang berkaitan dengan kehidupan sehari-hari yang berasal dari kitab shahih Bukahri, Muslim, Sunan Abi Dawud, Ibnu Majah, Tirmidzi, dan al-Nasa'i. Kitab-kitab tersebut dikenal dengan istilah kutub al-sittah. Walaupun kitab ini tidak membahas masalah kumis dan jenggot, tetapi seringkali ketika proses tanya jawab, pertanyaan terkait hal-hal ini muncul, sehingga penceramah mengemukakan pendapatnya yang merujuk pada hadis-hadis nabi.

Kumis sendiri menurut Kamus Besar Bahasa Indonesia adalah bulu atau rambut yang tumbuh di atas bibir atas dan biasanya hanya terdapat pada laki-laki. ${ }^{31}$ Sementara, jenggot atau janggut merupakan bulu yang tumbuh di dagu. ${ }^{32}$ Sebagimana diketahui bahwa Jamaah Tabligh merupakan kelompok yang berusaha untuk menghidupkan sunnah, maka tidak memelihara kumis atau mencukurnya ketika sudah tumbuh adalah bagian darinya. Sebaliknya, membiarkan jenggot adalah sebuah keniscayaan.

Dari wawancara penulis terhadap kelompok ini di masjid al-Ittihad juga menunjukkan demikian. Mereka memandang bahwa mencukur kumis dan memelihara jenggot adalah bagian

\footnotetext{
${ }^{28}$ Yahya, Ta'mir masjid Al Ittihad, 3 Oktober 2018.

${ }^{29}$ Furqan, "Peran Jamaah Tabligh dalam Pengembangan Dakwah", h. 6.

${ }^{30}$ Saifuddin Zuhri dan Subhani Kusuma Dewi, Living Hadis: Praktik, Resepsi, Teks, dan Transmisi, h. 39-

${ }^{31}$ https://kbbi.web.id/kumis, diakses 10 Oktober 2018.

32 https://kbbi.web.id/janggut, diakses 10 Oktober 2018.
} 41. 
dari sunnah. Jika kita mengacu kepada tipologi sunnah yang dikemukakan mereka, mencukur kumis dan memelihara jenggot termasuk ke dalam sunnah surah, yakni penampilan yang melekat kepada nabi secara fisik dalam kehidupan sehari-hari. Landasan tindakan mereka untuk selalu mencukur dan memendekkan kumis dan membiarkan jenggot adalah hadis-hadis sebagai berikut:

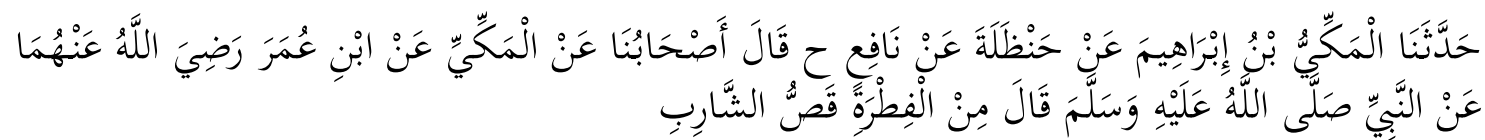

Artinya:

Telah menceritakan kepada kami Al Makki bin Ibrahim dari Hanzhalah dari Nafi', dan diriwayatkan dari jalur lain, sahabat-sahabat kami mengatakan; dari Al Makki dari Ibnu Umar radliallahu 'anhuma dari Nabi shallallahu 'alaihi wasallam bersabda: "Termasuk dari (sunnah) fitrah adalah mencukur kumis. (H.R. Bukhari) ${ }^{33}$

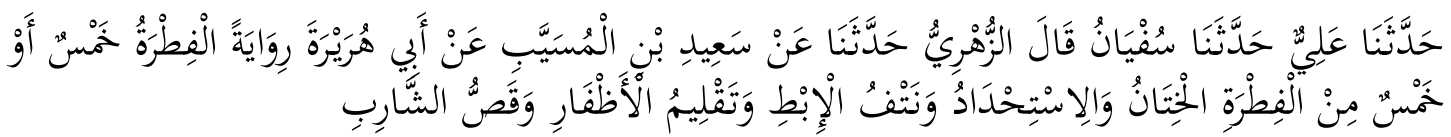

Artinya:

Telah menceritakan kepada kami Ali telah menceritakan kepada kami Sufyan, Az Zuhri mengatakan; telah menceritakan kepada kami dari Sa'id bin Musayyab dari Abu Hurairah secara periwayatan, (sunnah-sunnah) fitrah itu ada lima, atau lima dari sunnah-sunnah fitrah, yaitu; berkhitan, mencukur bulu kemaluan, mencabut bulu ketiak, memotong kuku dan mencukur kumis. (H.R. Bukhari) $)^{34}$

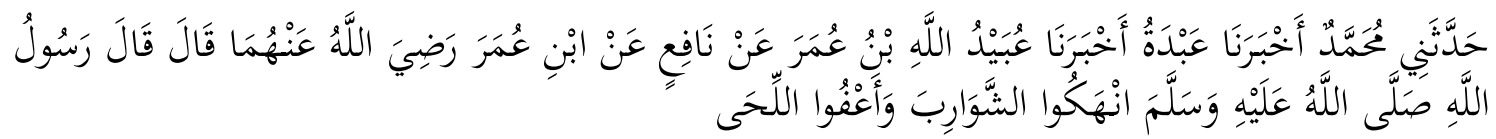

Artinya:

Telah menceritakan kepadaku Muhammad telah mengabarkan kepada kami Abdah telah mengabarkan kepada kami Ubaidullah bin Umar dari Nafi' dari Ibnu Umar radliallahu 'anhuma dia berkata; Rasulullah shallallahu 'alaihi wasallam bersabda: "Cukurlah kumis kalian dan biarkanlah jenggot kalian (panjang). (H.R. Bukhari) ${ }^{35}$

Dari ketiga hadis di atas yang paling populer di kalangan Jamaah Tabligh masjid alIttihad adalah hadis yang disebutkan terakhir yakni mencukur kumis dan memelihara jenggot, kemudian berturut-turut hadis ke-2 dan ke-1. Namun, ada juga sebagian jemaah yang tidak mengetahui teks hadisnya. Mereka hanya meyakini bahwa tidak memelihara kumis alias mencukurnya dan memelihara jenggot adalah bagian dari sunnah. Oleh karena itu, mereka melakukannya sebagai upaya meniru penampilan nabi yang dipandang sebagai salah satu bentuk ibadah.

${ }^{33}$ Abi Abdillah Muhammad bin Ismail al-Bukhari, Shahih al-Bukhari jilid IV, hadis no. 5888. (Beirut: Dar al-Kutub al-Ilmiyah, 2009), h. 64.

${ }^{34}$ Abi Abdillah Muhammad bin Ismail al-Bukhari, Shahih al-Bukhari jilid IV, hadis no. 5889, h. 64

${ }^{35}$ Abi Abdillah Muhammad bin Ismail al-Bukhari, Shahih al-Bukhari jilid IV, hadis no. 5893, h. 64. 


\section{Proses Ideologisasi Jamaah Tabligh di Masjid al-Ittihad}

Ideologi dalam hal ini mempunyai pengertian kumpulan gagasan yang menjadi panduan bagi sekelompok manusia dalam bertingkah laku untuk mencapai tujuan tertentu. Dengan cara menurunkan ideologi menjadi sebuah aksi dan aturan-aturan, sekelompok manusia bertindak membebaskan diri dari sesuatu yang dipersepsi sebagai kekangan atau penindasan. Ideologi memberi arah dan keyakinan kepada sebuah kelompok. ${ }^{36}$

Berdasarkan pada teori Bourdieu, habitus dalam Jamaah Tabligh masjid al-Ittihad adalah ajakan untuk menghidupkan sunnah yang dalam hal ini ialah selalu mencukur atau memendekkan kumis dan memelihara jenggot. Ajakan tersebut merupakan aturan tak tertulis yang telah disepakati sebagai sebuah pedoman bagi setiap individu dalam jamaah. Namun, aturan ini tidak bersifat mengikat. Artinya, ketika dalam jamaah terdapat orang yang berkumis dan tidak berjenggot tidak serta merta tidak dianggap sebagai bagian dari Jamaah Tabligh. Mereka akan tetap diakui dan diterima sebagai bagian dari kelompok tersebut, hanya mungkin saja akan terlihat asing di tengah-tengah komunitas yang tampak seragam.

Anjuran mencukur kumis dan memanjangkan jenggot merupakan kebenaran dominasi simbolik yang diyakini oleh setiap individu. Puncak dari dominasi simbolik ini dalam istilah Bordieu adalah doxa. Doxa adalah sejenis tatanan sosial dalam diri individu yang stabil dan terikat pada sebuah tradisi tanpa dipertanyakan. Doxa ini memiliki seorang tokoh yang dalam Jamaah Tabligh adalah Pak Yahya selaku takmir masjid al-Ittihad. Ia menjadi tokoh sentral Jamaah Tabligh di Yogyakarta. Ia pula yang mengorganisir segala kegiatan Jamaah Tabligh yang berlangsung di wilayah Jogja. Nasihatnya akan senantiasa diterima dan diyakini sebagai kebenaran tanpa mempertanyakan kembali.

Habitus yang berpuncak pada doxa membutuhkan sebuah wadah yang dalam istilah Bordieu adalah arena. Arena adalah sebuah komunitas yang di dalamnya proses ideologi ditanamkan. Arena dalam kasus ini adalah komunitas Jamaah Tabligh Yogyakarta yang berpusat di masjid al-Ittihad. Penyampaian dalam arena yang tepat akan berpengaruh terhadap jamaah.

Proses ideologisasinya berjalan melalui taklim-taklim yang diadakan di masjid al-Ittihad. Walaupun yang dikaji terbatas pada fadhail al-amal dan Riyad al-Shalihin, tetapi dalam proses tanya jawab masalah penampilan sering ditanyakan. Salah satunya adalah terkait dengan kumis dan jenggot. Hadis-hadis dalam kitab tersebut bersumber pada kitab induk hadis yang dikenal dengan kutub al-sittah, sehingga diakui kevalidannya dan dipercaya bersanad sampai nabi.

Dalam proses taklim tidak ada paksaan untuk para jamaah agar melaksanakan segala hal yang disampaikan. Perihal melakukan anjuran tersebut atau tidak hal itu dikembalikan kepada individu masing-masing karena dalam berdakwah tidak ada pemaksaan. Seperti penuturan Pak Yahya bahwasanya untuk melakukan sunnah nabi secara kaffah diperlukan mental yang kuat dari pelaku. Sehingga, penerapan sunnah pun dilakukan secara bertahap disesuaikan dengan kesiapan mental setiap jamaah. Kesadaran tersebut akan muncul seiiring berjalannya waktu dan intensitas jamaah dalam mengikuti kajian-kajian Tabligh.

36 Ibnu Muchlis, "Ideologisasi Salawat (Kajian Living Qur'an dalam Mafia Salawat Ponorogo)" Tesis Pascasarjana UIN Sunan Kalijaga, 2016, h. 86. 
Kesadaran menghidupkan sunnah sendiri (mencukur kumis dan memelihara jenggot) berawal dari kegelisahan Jamaah Tabligh terhadap fenomena kontemporer. Di era sekarang, umat Islam telah banyak yang meninggalkan sunnah dan lebih terpengaruh oleh budaya Barat. Untuk menangkis hal tersebut, maka diperlukan upaya-upaya menghidupkan sunnah sebagai sebuah identitas seorang muslim yang menjadikan nabi Muhammad sebagai tolak ukur segala tindakannya.

\section{Kesimpulan}

Mencukur kumis dan memanjangkan jenggot bagi Jamaah Tabligh di masjid al-Ittihad dipandang sebagai salah satu sunnah yang berkategori surah. Dengan melakukannya berarti telah menghidupkan salah satu sunnah nabi dan sekaligus menjadi identitas seorang muslim. Sunnah ini mempunyai legitimasi dari hadis nabi yang dapat ditemukan dalam kitab Shahih Bukhari yang disampaikan oleh penceramah dalam pengajiannya.

Adapun ditinjau berdasarkan teori Bourdieu, habitus dalam hal ini adalah anjuran untuk mencukur kumis karena dianggap sebagai sunnah. Sementara, yang berperan sebagai doxa ialah Pak Yahya sebagai takmir masjid al-Ittihad. Sedangkan, yang menempati posisi arena adalah kelompok Jamaah Tabligh di masjid al-Ittihad.

Proses ideologisasinya sendiri berlangsung melalui kajian-kajian atau taklim yang rutin diselenggarakan di masjid al-Ittihad. Tidak ada kewajiba bagi para anggota untuk mencukur kumis dan memelihara jenggot. Akan tetapi, dengan kajian yang dilakukan terus menerus mereka akan menyadari dan memahami bahwa mencukur kumis dan memanjangkan jenggot adalah sunnah. Dengan demikian, proses ideologisasinya dilakukan secara bertahap melalui taklim tanpa adanya paksaan. 


\section{DAFTAR PUSTAKA}

Abdillah, Abi Muhammad bin Ismail al-Bukhari, Shahih al-Bukhari jilid IV. Beirut: Dar alKutub al-Ilmiyah, 2009.

Ahmad, Gulam Musthafa, Menyingkap Tabir Kesalahpahaman Terhadap Jama'ah Tabligh, terj. Ahmad Najib Mahfuzh. Yogyakarta: Ash-Shaf, 1997.

Budimansyah. Gerakan Islam Jama'ah Tabligh dalam Tinjauan Maqashid al-Din, Jurnal Al'Adalah. Vol. X, No. 3, 2012.

Esposito, Jhon L. "Jama'ah Tablig", dalam Ensiklopedi Oxford Dunia Islam Modern, Jilid 4, terj. Eva,Y.N., dkk, ed. Ahmad Baiquni. Bandung: Mizan, 2001.

Furqan. Peran Jamaah Tabligh dalam Pengembangan Dakwah. Jurnal Al-Bayan, Vol. 21, No. 32, 2015.

Muchlis, Ibnu, “Ideologisasi Salawat (Kajian Living Qur'an dalam Mafia Salawat Ponorogo)”, Tesis. Yogyakarta: Pascasarjana UIN Sunan Kalijaga, 2016.

Mukhlis, Muhammad, “Telaah Hadis-Hadis yang Digunakan sebagai Hujjah Jama'ah Tabligh Masjid Jami’ Kebon Jeruk Jakarta Barat”, Skripsi. Jakarta: Fakultas Ushuluddin UIN Syarif Hidayatullah, 2011.

Nadwi, Sayyid Abu Hasan Ali Syari'ati, Maulana Muhammad Ilyas, terj. Masrokhan Ahmad. Yogyakarta: Ahs-Shaff, 1999.

Nasution, Harun, Pembaharuan dalam Islam, Sejarah Pemikiran dan Gerakan. Jakarta: Bulan Bintang, 1996.

Ningtyas, Eka. Pierre Bourdieu, Langue and Syimbolic Power. Jurnal Poetika, Vol. III, No. 2, 2015.

Ritzer, George dan Douglas Goodman, Teori Sosiologi Modern. Jakarta: Kencana, 2003.

Satyahadi, Ibnu, "Kegiatan Khuruj dan Dinamika Keluarga Jama'ah Tabligh (Studi pada Anggota Jama'ah Tabligh dan Keluarga di Masjid Jami’ Al-Ittihad Jalan Kaliurang Km. 5 Kecamatan Depok Kabupaten Sleman Provinsi Daerah Istimewa Yogyakarta)", Skripsi. Yogyakarta: Fakultas Ilmu Sosial dan Humaniora UIN Sunan Kalijaga, 2014.

Syayuman, Ismi, “Khuruj dalam Jama'ah Tabligh: Studi Terhadap Pengikut Jama'ah Tabligh di Masjid Jami' Al Ittihad Jalan Kaliurang KM. 5, Kecamatan Depok, Kabupaten Sleman, Provinsi Daerah Istimewa Yogyakarta", Skripsi. Yogyakarta: Fakultas Ushuluddin UIN Sunan Kalijaga, 2007.

Zaki, Muhammad. Metode Pemahaman dan Pengamalan Hadits Jamaah Tabligh. Jurnal Pengembangan Masyarakat Islam, Vol. 8, No. 2, 2015.

Zuhdi, M. Nurdin. Kritik Terhadap Pemikiran Gerakan Keagamaan Kaum Revivalisme Islam Di Indonesia. Akademika: Jurnal Pemikiran Islam, Vol. 16, No. 2, 2011.

Zuhri, Saifuddin dan Subhani Kusuma Dewi, Living Hadis: Praktik, Resepsi, Teks, dan Transmisi. Yogyakarta: Q-Media, 2018.

\section{Sumber Wawancara}


Wawancara dengan Bapak Yahya sebagai Ta'mir masjid Al Ittihad. Pada tanggal 3 Oktober 2018.

WEBSITE

https://kbbi.web.id/kumis, diakses pada tanggal 10 Oktober 2018. 